$\sqrt{3}$

J. bio-sci. 18: 116-120, 2010

ISSN 1023-8654

http://www.banglajol.info/index.php/JBS/index

\title{
PHOTOTHERAPY IN DIFFERENT STAGES OF BIRTH WEIGHT FOR THE TREATMENT OF NEONATAL HYPERBILIRUBINAEMIA
}

\author{
T Paul, R Parial, M A Hasem ${ }^{1}$, S Mojumder, M M Islam, M M Junaid², M Das ${ }^{3 *}$, M Alauddin \\ Department of Biochemistry and Molecular Biology, University of Chittagong, Chittagong, Bangladesh
}

\begin{abstract}
Context: The goal of phototherapy is to lower the concentration of circulating bilirubin or keep it from increasing in the treatment of neonatal unconjugated hyperbilirubinaemia. As phototherapy decrease billirubin level of infants, it is important to fix the dose of phototherapy.

Objectives: The aim of the study was to compare the effectiveness of double phototherapy versus conventional single phototherapy in the treatment of neonatal unconjugated hyperbilirubinaemia.

Materials and Methods: For this purpose 50 term and preterm newborns were enrolled. They were divided into 2 groups, 38 newborns were taken in group 1 and 12 newborn were taken in group 2. The babies who got conventional single phototherapy were taken in group 1. Each group was again divided into 3 subgroups according to their birth weight Normal Birth Weight (NBW), = Low Birth Weight (LBW) and Very Low Birth Weight (VLBW).

Results: The serum bilirubin level of term babies were found $17.32 \pm 4.08 \mathrm{mg} / \mathrm{dl}$ and in preterm babies were found $13.17 \pm 1.49 \mathrm{mg} / \mathrm{dl}$. Neonatal hyperbilirubinaemia in enrolled babies were due to physiologic jaundice (38\%), neonatal sepsis (50\%) and perinatal asphyxia (12\%). The serum bilirubin level in physiological jaundice was found $18.47 \pm 5.38 \mathrm{mg} / \mathrm{dl}$, in neonatal sepsis was found $14.90 \pm 1.85 \mathrm{mg} / \mathrm{dl}$ and in perenatal asphyxia was found $14.10 \pm$ $1.47 \mathrm{mg} / \mathrm{dl}$. Decline rate of serum bilirubin per day was found $4.58 \pm 2.43 \mathrm{mg} / \mathrm{dl}$ in NBW babies with the use of conventional single phototherapy compared to $6.27 \pm 2.26 \mathrm{mg} / \mathrm{dl}$ with the use of conventional double phototherapy. In LBW babies decline rate of serum bilirubin per day was found $2.07 \pm 0.84 \mathrm{mg} / \mathrm{dl}$ with the use of conventiona single phototherapy but $4.70 \pm 2.08 \mathrm{mg} / \mathrm{dl}$ with the use of conventional double phototherapy. In VLBW babies, decline rate of serum bilirubin per day was found $2.24 \pm 1.10 \mathrm{mg} / \mathrm{dl}$ with the use of conventional single phototherapy. Any VLBW babies which were given conventional double phototherapy were not found.

Conclusion: From this study it can be concluded that double phototherapy is more effective than conventional single phototherapy in the treatment of neonatal hyperbilirubinaemia in both groups of neonates; however the rate of fall of bilirubin was higher in NBW subgroups.
\end{abstract}

Keywords: Phototherapy, hyperbilirubinaemia, preterm, term.

Introduction

Jaundice is the visible manifestation in skin and sclera of elevated serum concentration of bilirubin. Neonatal jaundice may not appear until serum bilirubin exceeds 5 to $7 \mathrm{mg} / \mathrm{dl}$ (Madan et al. 2005). It is a commonly occurring condition that develops in $25-50 \%$ of term newborns and higher percentage infants (Martin and Cloherty 2004). Traditionally, a distinction has been made between physiologic jaundice and hyperbilirubinaemia, which is either pathologic in origin or severe enough to be considered for further evaluation and intervention. The later entity has been called 'nonphysiologic' although frequently no disease is identified as being causative or consequent. Any total serum bilirubin (TSB) elevation exceeding $17 \mathrm{mg} / \mathrm{dl}$ (291 umol/1) should be considered pathologic and warrants investigations for a cause and possible therapeutic intervention (Madan et al. 2005). Physiological jaundice is the commonest causes of neonatal jaundice. This is a transient unconjugated hyperbilirubinaemia in the neonatal period. Though neonatal hyperbilirubinaemia (NH) is not a major cause of mortality in our country but is observed during neonatal period, infancy or childhood. $\mathrm{NH}$ is a cause of concern for the parents, and paediatricians as well. It occurs in 5 - $10 \%$ of healthy term infants (Singhal et al. 1992). NH is the most common reason of readmission after early hospital discharge. Concerns regarding jaundice have increased after report of bilirubin induced brain damage occurring in healthy term infants even without haemolysis (Penn et al. 1994, Maisels and Newman 1995).

\footnotetext{
1 Department of Biochemistry and Biotechnology, University of Science \& Technology, Chittagong, Bangladesh

2 Chattagram Maa o Shisu Medical College Hospital, Chittagong, Bangladesh

3 Institute of Biological Sciences (IBSC), University of Rajshahi, Rajshahi, Bangladesh, e-mail: godisvip@gmail.com
} 
Neonatal jaundice occurred more often among East Asian and mixed Asian/white infants than among white infants. However, the risk of jaundice requiring extended hospital stay, rehospitalisation, phototherapy, or blood transfusion was elevated only for infants of full East Asian parentage (Setia et al. 2002). Subcommittee on hyperbilirubinaemia of the American Academy of Paediatrics (AAP 2004) gave some guidelines for the prevention of neonatal hyperbilirubinaemia. These guidelines provide 10 recommendations and the last one describes 'Treat newborns, when indicated, with phototherapy or exchange transfusion'. Total serum bilirubin (TSB) in infant discharged within $48 \mathrm{~h}$ of age generally shows an increasing trend and some of these infants later develop hyperbilirubinaemia. In a cohort of 500 healthy term infants, Alpay et al. (2000) found that hyperbilirubinaemia (serum bilirubin $>17 \mathrm{mg} / \mathrm{dll}$ ) commonly occurred after $72 \mathrm{~h}$ of age. As phototherapy decrease billirubin level of infants, it is important to fix the dose of phototherapy. Therefore the present study was undertaken to compare the effectiveness of double phototherapy versus conventional single phototherapy in the treatment of neonatal unconjugated hyperbilirubinaemia.

\section{Materials and Methods}

Subject, design and sample: Fifty term and preterm newborns were included from Neonatal unit, Department of Paediatrics and Department of Gynaecology, Chattagram Maa O Shisu General Hospital (CMSOGH) for the study. Total subject 50 (35 male, 15 female) which was divided into 2 groups; I) newborns who got conventional single phototherapy 38 subjects (28 male, 10 female), and II) newborns who got conventional double phototherapy 12 subjects ( 7 male, 5 female). Each group was again divided into 3 subgroups according to their birth weight; $A=$ Normal Birth Weight (NBW), $n=26 ; B=$ Low Birth Weight (LBW), $n=13$; and $\mathrm{C}=$ Very Low Birth Weight (VLBW), $\mathrm{n}=11$. All the subjects were matched according to age, sex, birth weight and gestational age of the newborn. Two $\mathrm{ml}$ of blood was collected from superficial vein of each subject. TSB was measured daily during phototherapy until it comes down the normal level. Age and weight were recorded in a data collection sheet.

Laboratory Investigations and phototherapy: TSB of newborn was measured from venous blood using Mod. Jendrassik and Grof's Method by an analyzer. Newborns with TSB level > 17mg/dl after 72 hours of life was defined to have significant hyperbilirubinaemia. Single or double phototherapy was selected depending upon the availability of phototherapy device in neonatal unit. Selection of double phototherapy preferably given when serum bilirubin in NBW is $>16 \mathrm{mg} / \mathrm{dl}$, in LBW $>14 \mathrm{mg} / \mathrm{dl}$ and in VLBW $>12 \mathrm{mg} / \mathrm{dl}$. In conventional single phototherapy, 5 fluorescent white tube light of 40 watts each with wave length of $450 \mathrm{~nm}$ were used at a distance of $45 \mathrm{~cm}$ from body surface. In double phototherapy, high radiance used under surface of the body and conventional single phototherapy given from above.

Ethical Consideration and data analysis: Informed parental consent was taken before enrolling the baby into the study. The procedure was fully explained to the parents and they were informed that the study would not hamper the treatment of the baby. Permission was also taken from the concerned departmental ethical committee in order to perform the study.

Analysis was done by employing Statistical Package for Social Science (SPSS Version 10.0) software package. Data were expressed as mean $\pm \mathrm{SD}$ and percentage. To compare mean values between groups, ttest was done as appropriate; $P<0.05$ was considered as minimum level of significance.

\section{Results}

Out of 50 enrolled newborn, 38 were in group I and 12 were in group II. Males were $70 \%$ of total subjects, where $56 \%$ were in group I and $14 \%$ in group II. The reaming $30 \%$ females were distributed as $20 \%$ in group I and 10\% in group II. The distributions of birth weights of enrolled neonates were NBW $52 \%$, where $38 \%$ in group I and 14\% in group II; LBW $26 \%$ where $16 \%$ in group I and 10\% in group II; and VLBW were 22\%, all 
in group I (Table 1). According to gestational age of newborn babies, preterm were 16 (32\%) where, 30\% were in group I and $2 \%$ in group II. Term babies were $34(68 \%)$, where $46 \%$ were in group I and $22 \%$ in group II. The serum bilirubin level of preterm babies was $13.17 \pm 1.49 \mathrm{mg} / \mathrm{dl}$ and in term babies it was $17.32 \pm 4.08 \mathrm{mg} / \mathrm{dl}$ (Table 2). The neonatal hyperbilirubinaemia was due to physiologic Jaundice in $38 \%$ cases, neonatal sepsis in $50 \%$ cases and perinatal asphyxia in $50 \%$ cases

The TSB level was $18.47 \pm 5.38 \mathrm{mg} / \mathrm{dl}$ in physiological jaundice, $14.90 \pm 1.45 \mathrm{mg} / \mathrm{dl}$ in neonatal sepsis and $14.10 \pm 1.47 \mathrm{mg} / \mathrm{dl}$ in perinatal asphyxia (Table 2). In NBW babies, TSB levels before and after phototherapy were found $19.5 \pm 2.9$ and $13.4 \pm 2.4 \mathrm{mg} / \mathrm{dl}$ respectively $(p<0.001)$ in conventional single phototherapy with decline rate of $0.19 \pm 0.10 \mathrm{mg} / \mathrm{d} / \mathrm{h}$ and $4.58 \pm 2.43 \mathrm{mg} / \mathrm{dl} / \mathrm{day}$. In conventional double phototherapy, TSB levels before and after phototherapy was $26.4 \pm 5.5$ and $13.1 \pm 3.4 \mathrm{mg} / \mathrm{dl}$ respectively $(p<0.001)$ with decline rate of $0.26 \pm 0.09 \mathrm{mg} / \mathrm{d} / \mathrm{h}$ and $6.27 \pm 2.26 \mathrm{mg} / \mathrm{d} / \mathrm{day}$, which was highly significant $(p<0.001)$ in both cases. The decline rate of serum bilirubin was higher in conventional double phototherapy than conventional single phototherapy (Table 3). In LBW babies, TSB levels before and after phototherapy was found $16.1 \pm 1.75$ and $12.7 \pm 1.26 \mathrm{mg} / \mathrm{dl}$ respectively in conventional single phototherapy having decline rate of $0.09 \pm 0.03 \mathrm{mg} / \mathrm{d} / \mathrm{h}$ and $2.07 \pm 0.84 \mathrm{mg} / \mathrm{d} / \mathrm{day}$. In conventional double phototherapy, TSB levels before and after phototherapy was $23.3 \pm 3.46$ and $13.96 \pm 2.07 \mathrm{mg} / \mathrm{dl}$ respectively having decline rate of $0.20 \pm 0.08 \mathrm{mg} / \mathrm{d} / \mathrm{h}$ and $4.70 \pm 2.08 \mathrm{mg} / \mathrm{d} / \mathrm{day}$. It was highly significant $(p<0.001)$ in case of conventional double phototherapy but it was not significant for conventional single phototherapy (Table 3), In VLBW babies, TSB before and after phototherapy was $13.47 \pm 1.87$ and $9.28 \pm 1.81 \mathrm{mg} / \mathrm{dl}$ respectively for conventional single phototherapy $(P<0.001)$ with decline rate of $0.09 \pm 0.07 \mathrm{mg} / \mathrm{d} / \mathrm{h}$ and $2.24 \pm 1.10$ $\mathrm{mg} / \mathrm{d} / \mathrm{day}$. Any VLBW baby who was given conventional double phototherapy was not found (Table 3 ).

Table 1. Percentage of group I and group II babies in three categories of birth weight,

\begin{tabular}{|c|c|c|c|c|c|c|}
\hline \multirow{2}{*}{$\begin{array}{l}\text { Categories of } \\
\text { Birth weights } \\
(\%)\end{array}$} & \multirow[t]{2}{*}{$\begin{array}{c}\text { Group I (\%) } \\
(n=38)\end{array}$} & \multirow[t]{2}{*}{$\begin{array}{c}\text { Group II (\%) } \\
(n=12)\end{array}$} & Types of Patients & \multicolumn{2}{|c|}{ No. of Patients(\%) } & \multirow{3}{*}{$\begin{array}{c}\begin{array}{c}\text { Bilirubin } \\
\text { Level (mg/dl) }\end{array} \\
13.17 \pm 1.49\end{array}$} \\
\hline & & & \multirow{2}{*}{ Preterm } & \multirow{2}{*}{$16(32)$} & Group I (30) & \\
\hline NBW (52) & 38 & 14 & & & Group II (2) & \\
\hline \multirow{2}{*}{ LBW (26) } & \multirow[t]{2}{*}{16} & \multirow[t]{2}{*}{10} & Term & $34(68)$ & $\begin{array}{l}\text { Group I ( 46) } \\
\text { Group II(22) }\end{array}$ & $17.32 \pm 4.08$ \\
\hline & & & Physiologic Jaundice & $19(38)$ & & $18.47 \pm 5.38$ \\
\hline VLBW( 22) & 22 & 0 & $\begin{array}{l}\text { Neonatal sepsis } \\
\text { Perinatal asphyxia }\end{array}$ & $\begin{array}{l}25(50) \\
6(12)\end{array}$ & & $\begin{array}{l}14.90 \pm 1.85 \\
14.10 \pm 1.47\end{array}$ \\
\hline
\end{tabular}

Table 3. Bilirubin levels of NBW (Normal Birth Weight), LBW (Low Birth Weight) and VLBW (Very Low Birth Weight) neonates before and after single and double phototherapy.

\begin{tabular}{lccccccc}
\hline \multirow{2}{*}{ Birth weight } & Phototherapy & \multicolumn{2}{c}{ Serum Bilirubin (mg/dl) } & \multirow{2}{*}{ p value } & Duration (h) & $\begin{array}{c}\text { Decrement/h } \\
(\mathrm{mg} / \mathrm{dl})\end{array}$ & $\begin{array}{c}\text { Decrement/24h } \\
(\mathrm{mg} / \mathrm{dl})\end{array}$ \\
\cline { 2 - 4 } & Before & After & & & & & \\
\multirow{2}{*}{ NBW } & Single & $19.5 \pm 2.9$ & $13.4 \pm 2.4$ & $<0.001$ & $31.52 \pm 14.22$ & $0.19 \pm 0.10$ & $4.58 \pm 2.43$ \\
& Double & $26.4 \pm 5.5$ & $13.1 \pm 3.4$ & $<0.001$ & $50.00 \pm 10.56$ & $0.26 \pm 0.09$ & $6.27 \pm 2.26$ \\
\hline \multirow{2}{*}{ LBW } & Single & $16.1 \pm 1.75$ & $12.7 \pm 1.26$ & $>0.05$ & $38.42 \pm 11.65$ & $0.09 \pm 0.03$ & $2.07 \pm 0.84$ \\
& Double & $23.3 \pm 3.46$ & $13.96 \pm 2.07$ & $<0.001$ & $47.00 \pm 8.72$ & $0.20 \pm 0.08$ & $4.70 \pm 2.08$ \\
\hline \multirow{2}{*}{ VLBW } & Single & $13.47 \pm 1.87$ & $9.28 \pm 1.81$ & $<0.001$ & $44.19 \pm 16.42$ & $0.09 \pm 0.07$ & $2.24 \pm 1.10$ \\
\hline
\end{tabular}




\section{Discussion}

Neonatal jaundice stems from a transient deficiency of conjugation (exacerbated in preterm infants) combined with increased turnover of red cells. Pathologic conditions that can increase bilirubin production include isoimmunization, heritable hemolytic disorders, and extravasated blood (e.g., from bruises and cephalhematomas) (Maisels 2005). The goal of therapy is to lower the concentration of circulating bilirubin or keep it from increasing. Phototherapy achieves this by using light energy to change the shape and structure of bilirubin, converting it to molecules that can be excreted even when normal conjugation is deficient (Lightner and McDonagh 1984). Absorption of light by dermal and subcutaneous bilirubin induces a fraction of the pigment to undergo several photochemical reactions that occur at very different rates. These reactions generate yellow stereoisomers of bilirubin and colourless derivatives of lower molecular weight (Maisels and McDonagh 2008). The products are less lipophilic than bilirubin, and unlike bilirubin, they can be excreted in bile or urine without the need for conjugation. The relative contributions of the various reactions to the overall elimination of bilirubin are unknown, although in vitro and in vivo studies suggest that photoisomerization is more important than photodegradation (Lightner and McDonagh 1984). Bilirubin elimination depends on the rates of formation as well as the rates of clearance of the photoproducts. Photoisomerization occurs rapidly during phototherapy, and isomers appear in the blood long before the level of plasma bilirubin begins to decline (Maisels and McDonagh 2008).

Phototherapy is now widely accepted as a safe and effective method for management of NH. Phototherapy detoxifies bilirubin and facilitates its excretion by the kidneys. In term infants, double phototherapy with a fiber-optic blanket has been reported to be more effective in reducing bilirubin than conventional phototherapy (Nuntnarumit 2002). In this study, male were $70 \%$ and female were $30 \%$. Here percentage of male is greater than female. This is supported by the study of Lewis et al. (1982), where male remain jaundiced for significantly higher than female.

In a previous study (Rashid et al. 2003), preterm babies were 26.50\%. The TSB level of preterm babies was $13.17 \pm 1.49 \mathrm{mg} / \mathrm{dl}$ and in term babies it was $17.32 \pm 4.08 \mathrm{mg} / \mathrm{dl}$ respectively which is almost similar to the study done by William and Cashore (1980). In preterm neonates double phototherapy is more effective than single phototherapy (Kang and Shankaran 1995). Rashid et al. (2003) observed NH due 26.03\%, physiologic jaundice $19.95 \%$ and perinatal asphyxia $16.52 \%$. In the present study, the percentages are higher, because in their study they considered many complications like sepsis, pneumonia, meningitis, premature babies, neonatal jaundice, and birth asphyxia.

Zahedpasha et al. (2006) studied $19.70 \pm 1.60 \mathrm{mg} / \mathrm{dl}$ TSB level in single phototherapy which is similar to the present study but in double phototherapy the bilirubin level was $20.3 \pm 2.4 \mathrm{mg} / \mathrm{dl}$ which is lower than this study. In this study only three NBW neonates were found which had bilirubin level $>30.0 \mathrm{mg} / \mathrm{dl}$. Decline rate of TSB in conventional single and double phototherapy suggests that phototherapy is an important therapeutic method for NBW neonates and double phototherapy seems to be a better therapeutic approach than single phototherapy. This result is almost alike to the study of Payon et al. (2008), who found that the decline rate of serum bilirubin in conventional single and double phototherapy was $3.50 \pm 1.70 \mathrm{mg} / \mathrm{d} / \mathrm{day}$ and $5.40 \pm 2.00 \mathrm{mg} / \mathrm{d} / \mathrm{day}$. This result is supported by other studies (Kang and Shankaran 1995, Sarici et al. 2000, Maisels 2006). In VLBW neonates, the decline rate of serum bilirubin was found $0.09 \pm 0.07$ $\mathrm{mg} / \mathrm{d} / \mathrm{hr}$ and $2.24 \pm 1.10 \mathrm{mg} / \mathrm{d} / \mathrm{day}$ with conventional single phototherapy which is consistent with study of Maisels (2006). The decline rate was slower in VLBW neonates compared to NBW and higher than LBW. 


\section{Conclusions}

From this above discussion it can be concluded that double phototherapy is more effective than conventional single phototherapy in the treatment of neonatal hyperbilirubinaemia in both groups of neonates; however the rate of fall of bilirubin was higher in NBW subgroups.

\section{References}

AAP (American Academy of Pediatrics). 2004. Clinical practice guideline: Management of Hyperbilirubinemia in the Newborn Infant 35 or More Weeks of Gestation. Pediatrics 114(1), 297-316. http://dx.doi.org/10.1542/peds.114.1.297 PMid:15231951

Alpay F, Sarici SU, Tosuncuk HD, Serdar MA, Inanc N, Gokcay E. 2000. The value of first-day bilirubin measurement in predicting the development of significant hyperbilirubinaemia in healthy term newborns. Pediatrics 16, 16-21. http://dx.doi.org/10.1542 /peds.106.2.e16 PMid:10920172

Kang JH, Shankaran S. 1995. Double phototherapy with high irradiance compared with single phototherapy in neonates with hyperbilirubinaemia. Amer J Perinatol. 12(3), 178-180. http://dx.doi.org/10.1055/s-2007-994446 PMid:7612090

Lewis HM, Campbell RH, Hambleton G. 1982. Use of abuse of phototherapy for physiological jaundice of newborn infants. Lancet 2 , 408-410.

Lightner DA, McDonagh AF. 1984. Molecular mechanisms of phototherapy for neonatal jaundice. Accts Chem Res 17, 417-24. http:/l dx.doi.org/10.1021/ar00108a002

Madan A, MacMahon JR, Stevenson DK. 2005. Neonatal hyperbilirubinaemia. In: Taeusch HW, Ballard RA, Gleason CA, (eds) Avery's disease of the newborn. 8th ed. Philadelphia: Saunders, pp.1227-1256.

Maisels MJ, McDonagh AF. 2008. Phototherapy for Neonatal Jaundice. N Engl J Med 358, 920-928. http://dx.doi.org/ 10.1056/NEJMct0708376 PMid:18305267

Maisels MJ, Newman TB. 1995. Kernicterus in otherwise healthy breastfed term newborns. Pediatrics 96(4), 730-733. PMid:7567339

Maisels MJ. 2005. Jaundice. In: MacDonald MG, Mullett MD, Seshia MMK, (eds). Avery's neonatology: pathophysiology and management of the newborn. Philadelphia: Lippincott Williams \& Wilkins, 768-846.

Maisels MJ. 2006. Neonatal jaundice. Paediatr Rev 27(12), 443-453. http://dx.doi.org/10.1542/pir.27-12-443

Martin CR, Cloherty JP. 2004. Neonatal Hyperbilirubinaemia in manual of neonatal care. $5^{\text {th }}$ ed. Lippincott Williams \& Wilkins, Phiadelohia, 185-221.

Nuntnarumit P. 2002. Comparison or the effectiveness between the adapted-double phototherapy versus conventional-single phototherapy. J Med Assoc Thai 85 (4), 1159-66.

Payon BP, Warawut KW, Kannikar BK. 2008. Effectiveness of double-surface intensive phototherapy versus single-surface intensive phototherapy for neonatal hyperbilirubinaemia. J Med Assoc Thai 91(1):50-55. PMid:18386544

Penn AA, Enzman DR, Han JS, Stevenson DK. 1994. Kernicterus in a full term infant. Paediatrics 93(6):1003-1006.

Rashid A, Ferdous S, Chowdhury T, Rahman F. 2003. Morbidity pattern and hospital outcome of neonates admitted in tertiary level hospital in Bangladesh. Bangladesh J Child Health 27, 10-13.

Sarici SU, Alpay F, Unay B, Ozcan O, Gokcay. 2000. Double versus single phototherapy in term newborns with significant hyperbilirubinaemia. J Trop Padiatr 46(1), 36-39. http://dx.doi.org/10.1093/tropej/46.1.36

Setia S, Villaveces A, Dhillon P, Mueller AB. 2002. Neonatal jaundice in Asian, White and Mixed race infants. Arch Pediatr Adolesc Med 156, 276-279. PMid:11876673

Singhal P, Singh M, Paul VK, Deorari AK, Ghorpade MG. 1992. Spectrum of neonatal hyperbilirubinaemia: An analysis of 454 cases. Indian Padiatr 29, 319-325. PMid:1612673

William MD, Cashore J. 1980. Free bilirubin concentrations and bilirubin binding affinity in term and preterm infants. J Paediatr 96(2), 521-527.

Zahedpasha Y, Ahmadpour M, Fuladinejat M, Alizadeh R, Mazlomi A. 2006. Single and double versus intensive phototherapy in term newborns with severe hyperbilirubinaemia. Iran J Pediatr 16, 1-5. 